\title{
Management of adult tuberous sclerosis complex-related angiomyolipoma: A single-center experience
}

Terry Li*; Meghna Siddoji*; Jen Hoogenes; Camilla Tajzler; Nikhita Singhal; Anil Kapoor Department of Surgery, Division of Urology, McMaster University, Hamilton, ON, Canada ${ }^{*}$ Co-first authors

Cite as: Li T, Siddoji M, Hoogenes J, et al. Management of adult tuberous sclerosis complexrelated angiomyolipoma: A single-center experience. Can Urol Assoc J 2021 December 21; Epub ahead of print. http://dx.doi.org/10.5489/cuaj.7556

Published online December 21, 2021

Corresponding author: Dr. Anil Kapoor, Division of Urology, Department of Surgery McMaster University/St. Joseph's Healthcare Hamilton, Hamilton, ON, Canada; akapoor@mcmaster.ca

$* * *$

\section{Abstract}

Introduction: Tuberous sclerosis complex (TSC) is a rare, multisystem, genetic disease. A significant cause of TSC-related morbidity is potential bleeding from renal angiomyolipoma (AML). To pre-emptively decrease AML bleeding, mTOR inhibitors can be used; however, thresholds for initiating and maintaining everolimus therapy remain uncertain. Recent literature suggests not triggering active treatment of AMLs based on size thresholds alone. We evaluated the appropriateness of initiating everolimus therapy in asymptomatic patients after considering AML size, rate of growth, and other factors.

Methods: Diagnostic criteria developed by the 2012 International TSC Consensus Group and presence of AML were used as inclusion criteria. Medical and imaging reports of 20 TSC patients from a single center were reviewed.

Results: Mean age was $40.55( \pm 16.27)$ and 11 patients were female. Eight asymptomatic patients at high risk for complications underwent everolimus therapy, of which seven (88\%) demonstrated decreased AML size but multiple side effects were reported. Four high-risk asymptomatic patients did not undergo therapy due to side effect concerns, while four low-risk asymptomatic patients had stable AMLs under active surveillance. Four patients had reduced AMLs through local therapy.

Conclusions: Everolimus treatment was effective for managing AML size in most high-risk asymptomatic patients with tolerable side effects. AML size can remain relatively stable for 
asymptomatic low-risk patients despite not receiving intervention(s). Patients with TSC-related AML can be safely managed with mTOR inhibitors like everolimus, with shared decisionmaking including factors such as bleeding risk, AML growth rate, and number and absolute size of AMLs.

\section{Introduction}

Tuberous sclerosis complex (TSC) is rare genetic disease that can affect multiple organ systems. An estimated 2 million individuals are affected by TSC worldwide, with an approximate birth incidence rate of 1 in 6,000-10,000. ${ }^{1,2}$ All ethnicities and both sexes are affected. ${ }^{3}$ TSC is caused by loss of function mutations in the TSC1 and/or TSC2 gene. Around one-third of individuals with TSC inherit the mutations, whereas two-thirds carry spontaneous mutations. ${ }^{1}$ Hamartin and tuberin, the protein products of TSC1 and TSC2, respectively, bind with a third protein (TBC1D7) to form the TSC protein complex. ${ }^{3}$ Typically, this complex negatively regulates the mechanistic target of rapamycin (mTOR) signalling pathway, which in turn regulates activities such as cell growth and proliferation. ${ }^{1}$ In the absence of properly functioning hamartin and/or tuberin, enhanced mTOR activation results in unregulated cellular growth.

Clinical features of TSC are well characterized but can vary widely between individuals. ${ }^{1}$ Presentations of TSC have been found to involve any organ system. ${ }^{1}$ Examples of TSC features include renal angiomyolipomas (AMLs), pulmonary lymphangioleiomyomatosis (LAM), and hamartomas found throughout the body. ${ }^{1,2}$ Neurological manifestations of TSC include subependymal nodules (SENs), malformations of the cerebral cortex (tubers), subependymal giant cell astrocytomas (SEGA), epilepsy, and TSC-associated neuropsychiatric disorders (e.g., autism spectrum disorder; cognitive disability). ${ }^{1,2}$ AMLs are benign tumours comprised of smooth muscle and vascular and adipose tissue. ${ }^{2}$ Despite their benign nature, renal AMLs are the most common cause of TSC-related death due to the risk of hemorrhage and subsequent renal failure. ${ }^{2,4}$ Abnormal vasculature present in renal AMLs may cause weak spots in blood vessels, with AMLs $>3 \mathrm{~cm}$ in diameter most at risk of causing hemorrhage. ${ }^{1}$ Consequently, renal AML management is an important area of focus for TSC clinical management and research.

Embolization is the first line of treatment for acute bleeding in AMLs, and is successful by blocking blood supply to the tumour. ${ }^{1}$ In a pre-emptive attempt to prevent this bleeding, systemic mTOR inhibitor (mTORi) therapy is the preferred method. ${ }^{1}$ Compared to embolization, mTORi therapy better avoids collateral damage to normal renal tissue which may exacerbate risk of later impaired renal function. Everolimus is an orally ingested mTORi used to manage AML size. The effectiveness of everolimus in reducing AML volume has been reported in the literature, which has shown support of its use. ${ }^{1,5}$ 
The threshold for initiating everolimus therapy remains uncertain. International guidelines published in 2013 recommend pre-emptively treating lesions that are $>3 \mathrm{~cm}$ in diameter and still growing. ${ }^{1}$ These recommendations state that regular surveillance should be used for AMLs not meeting these criteria. However, recent papers have presented qualitative data to argue against triggering active treatment of AMLs based on size thresholds alone. ${ }^{6,7}$ The objective of this study was to evaluate the appropriateness of initiating everolimus therapy in TSC patients with asymptomatic AMLs based on established AML treatment criteria, while also assessing patient experiences with side effects and other treatment burdens. A qualitative approach was used to allow for a greater focus on TSC patient perspectives, which is poorly represented in the available literature.

\section{Methods}

Following institutional research ethics board approval, the electronic medical records of all patients aged 18 and older treated at our center for TSC-related symptoms between 2014 and 2019 were reviewed. Inclusion was based on the diagnostic criteria published by the 2012 International Tuberous Sclerosis Complex Consensus Group. ${ }^{8}$ Table 1 summarizes the TSC diagnostic criteria. ${ }^{8}$ For inclusion in the study, patients were required to have asymptomatic AMLs. Twenty-one patients had a definitive TSC diagnosis and were included in the analysis. Chart data, including the initiation of everolimus, were extracted up until the patient's most recent clinic visit.

Prior to initiation of any interventions, all patients had comprehensive clinical and radiological workups. Data on change in AML size for all patients were captured via imaging scans. Characteristics of AMLs were used to estimate the effect of everolimus effectiveness in the management of TSC. The percent change in AML size in response to everolimus dosage was calculated using values from imaging tests. Initial AML size was approximated using the last imaging test preceding the start date for everolimus therapy. Final AML size was estimated using the imaging results prior to an everolimus dosage change. Records were also evaluated for patient experiences including side effects and treatment burdens. Side effects and other experiences noted were maintained in the study records and a qualitative profile was created for each patient.

\section{Results}

Of 21 TSC patients treated at our center, 20 met study inclusion criteria. The mean age of study participants was $40.55 \pm 16.27$ (range 16-77), the mean age at diagnosis was $24 \pm 18.9$ (range 047), and 11 were female. For ease of reporting individual patients' results and experiences, each patient was assigned a unique identification number. All patients demonstrated renal involvement, while 15 experienced neurological manifestations and 10 had other organ involvement. Of the 6 patients who had genetic testing for TSC, 4 were positive, 1 was negative, 
and 1 was unknown. Table 2 shows the age, sex, genetic testing status, and the TSC-related manifestations for each patient.

Eight patients underwent everolimus treatment during the study period. Table 3 summarizes the type(s) of therapy administered, including surgery, embolization, and/or everolimus, as well as whether acute renal AML bleed occurred. For the five patients who underwent surgery and/or embolization prior to everolimus, the previous intervention(s) did not have an effect on AML size. Eight patients received no intervention. Table 4 notes the reported side effects and clinical benefits for individual everolimus patients, while Table 5 outlines the specific everolimus dosage at which AML size changes, clinical benefits, and side effects were observed, as well as noted reason(s) for dosage change (if any) in individual patients.

Of the 8 patients on everolimus, we evaluated the effectiveness in 7 patients, as one patient (\#18) had only recently begun treatment at the time of data extraction. However, this patient's chart had available data that were useful for the overall findings of the study. All everolimus therapy patients were categorized as high-risk asymptomatic, as they had asymptomatic AMLs but a higher risk of secondary complications (e.g., greater risk of hemorrhage with lesions $\geq 3 \mathrm{~cm}$, low functional kidney reserves, rapidly growing tumours).

\section{Individual patient findings}

Eight patients $(1,5,8,14,15,18,20,21)$ received everolimus and those evaluated all had some decrease in AML size upon initiating therapy. Further details about AML size changes are described in Table 5. Figure 1 provides a visual example of AML size prior to therapy (a) and the decrease in AML size after 9 months of everolimus therapy in patient 21(b).

Everolimus was initially proposed in the clinical setting to 4 patients (patients 2, 6, 7 and 9) for AML size reduction, as surgery or angioembolization of their large AMLs would have increased the risk of renal function loss and were not advisable options. Patients 2, 6, and 9 had large bilateral AMLs which were at high risk of renal hemorrhage; however, these patients were reluctant to start everolimus due side effect concerns and instead chose active surveillance. Patient 7 had a solitary kidney with large AMLs, making them an everolimus candidate; however, due to mobility and cognitive disabilities that posed treatment maintenance challenges, everolimus was not initiated.

Patients 10,11,13, and 16 had asymptomatic AMLs with low risk for secondary complications; as such, they underwent active surveillance. For surveillance patients 11, 13, and 16 , the AML size percent change was $+8 \%$ ( 2 -year span), $+4 \%$ ( 3 -year span), and $-4 \%$ ( 1 -year span), respectively. While patient 10 's percent change was $+100 \%$, this value corresponds to an absolute change of 3-4 mm in AML size over a 5-year span. Patients 3, 4, 12 and 19 were not candidates for either active surveillance or everolimus therapy. For this group, AMLs were reduced through localized therapies such as nephrectomy and radiofrequency ablation. Patient 17 did not have AMLs and was excluded from the study. 


\section{Discussion}

Data from the patients in this study who underwent everolimus treatment suggest that it is an effective therapy for managing AML size in asymptomatic high-risk TSC patients. This aligns with the conclusions of the multicenter phase III EXIST-2 clinical trial $(\mathrm{n}=188)$, which found reductions in sum AML volumes in $95 \%$ of everolimus patients. ${ }^{5}$ Additional clinical studies have observed statistically significant reductions of AML volumes with everolimus compared to placebo. A single center study by $\mathrm{Ni}$ et al. found at least $50 \%$ reduction in $63.33 \%(19 / 30)$ of patients after 12 weeks of everolimus treatment. ${ }^{9}$ Similarly, a 2014 randomized controlled trial (RCT) found a 55.3\% (16/30) AML response rate for everolimus patients compared with $0 \%$ $(0 / 14)$ on placebo after 48 weeks of treament. ${ }^{10}$

In our study, when everolimus treatment was stopped, AML size generally increased. This has been shown in other studies where AML sizes approached baseline values when everolimus therapy was terminated. ${ }^{10,11}$ Our data also suggest that everolimus is effective in improving other TSC-associated manifestations such as skin lesions and seizures, which supports findings in previous studies. ${ }^{12,13} \mathrm{~A}$ case study reported that facial angiofibromas were successfully treated with everolimus ointment without apparent side effects. ${ }^{13}$ Additionally, the EXIST-3 study, a large multicenter study, found that everolimus improved skin lesions in $58.1 \%$ patients $(\mathrm{n}=105)$. The study focused on the efficacy of everolimus as a treatment option for SEGAs, and found that over half of patients had reduced SEGA lesion volumes, in the absence of new target lesions, and new or worsening hydrocephalus. ${ }^{12}$ Krueger et al., found that everolimus reduced seizure frequency in 12 of 20 subjects, demonstrating additional benefits in behaviour and quality of life. ${ }^{14}$

Systemic treatments are currently recommended as the first-line treatment for asymptomatic TSC patients to preserve renal parenchyma, reduce rate of secondary complications, and/or reduce the need for continued interventions which may further compromise renal function. ${ }^{15,16,17}$ While four study participants (patients $3,4,12,19$ ) managed their AMLs through localized therapy, they were not candidates for everolimus therapy or active surveillance as they had either symptomatic AMLs and/or extremely high-risk AMLs.

Four of our study participants (patients 10,11,13,16) had stable AMLs despite not receiving angioembolization, everolimus, or TSC-related surgery for reducing AML size. With the exception of patient 16 who had a single instance of hematuria years prior to discovering their AMLs, these patients did not experience acute renal bleeds or any other significant TSCrelated adverse events. With asymptomatic AMLs and lower risk of secondary complications, these study participants can be considered low-risk asymptomatic patients. These findings suggest that active surveillance in low-risk asymptomatic AML patients is a viable option, which aligns with the current strategy recommendations. ${ }^{15,16}$ Please refer to Figure 2 for a management algorithm for TSC-associated AMLs. 
The side effects of everolimus therapy may detract patients from starting or continuing treatment. While many known everolimus side effects (e.g., mucositis, nausea, and headaches) are generally well-tolerated, the impact of these adverse events on patients' daily lives can differ widely. For example, patient 14 in our study had mucositis that was only marginally improved by viscous lidocaine mouthwash. While not considered a high-grade adverse event, mucositis combined with weight loss was enough to warrant a decrease in everolimus dosage in this patient. Two patients in our study ( 2 and 6 ) were excellent everolimus candidates but declined due to side effect concerns. Patient 21 was hesitant in continuing everolimus after experiencing side effects on $5 \mathrm{mg}$, which persisted after being decreased to $2.5 \mathrm{mg}$.

Symptoms, tumour sizes, and renal function of TSC patients on observation protocols are generally evaluated every 6-12 months as part of active surveillance. However, TSC patients on everolimus are typically evaluated every 6-8 weeks with $\mathrm{CBC}$, electrolytes, creatinine, and urinalysis until stabilization, then every 3-4 months afterwards. ${ }^{15}$ Some patients may not be able to adhere to this schedule, which may also include frequent imaging procedures. In our study, two patients with TSC manifestations and/or comorbidities were unable to undergo everolimus therapy because their circumstances did not allow for adequate monitoring required while on the treatment. Clinicians need to consider this in the TSC patient population, as for low-risk asymptomatic patients, the burdens associated with everolimus therapy may not be worth the relatively smaller benefit received compared to those in the high-risk patient population.

Another burden to everolimus therapy can be financial cost. At approximately $\$ 186$ per $10 \mathrm{mg}$ tablet, patients may experience financial difficulties in affording the drug. While programs such as Ontario's (Canada) Exceptional Access Program (EAP) provide funding for everolimus treatment of TSC-related AMLs, not all TSC patients receive funding approval and must obtain financial assistance through other means. Furthermore, the process of applying for financial funding is lengthy and uncertain. One patient in our study was initially denied assistance through the EAP program before being given approval after 6 months. An additional burden arises from new medications that are prescribed to manage everolimus-related side effects. These new medications can potentially impact the quality of life of patients with already extensive medication lists. For instance, one patient in our study was taking $>25$ different medications prior to receiving everolimus. Upon initiating everolimus, the patient experienced elevated triglycerides and cholesterol levels which required additional medications to manage. The potential treatment burdens associated with everolimus support comprehensive clinician counseling with eligible patients, including the weighing of risks and benefits, so that informed treatment decisions can be made.

As noted previously, the determining point for initiating intervention for TSC-associated AMLs has generally been a size cut-off. ${ }^{1,18,19,20}$ However, a consensus for this practice has still not been reached. For example, a recent literature review of renal AML research proposed a larger AML cut-off size to prevent overtreatment of AMLs. ${ }^{16}$ Other papers have also suggested 
that AML size is not the only factor that needs to be considered. ${ }^{6,15}$ In our center, multiple variables (AML size, size of aneurysms, disease burden, functional kidney reserves, AML location, growth rate, etc.) were used to determine risk of secondary complications arising from renal AMLs in asymptomatic TSC patients. High-risk asymptomatic patients received everolimus therapy while low-risk asymptomatic patients were placed under active surveillance. The favorable AML size outcomes for both groups offer support for using other factors alongside AML size to determine the appropriate treatment plan for asymptomatic TSC-associated AMLs. For initiation of everolimus specifically, treatment burdens (potential impacts of drug side effects on quality of life, the toll of increased monitoring appointments, and financial stress) present another factor which needs to be considered.

This study is not without its limitations. The sample size is small at 20 and patient data are from a single center; however, as TSC is a rare disease, a low sample size would be expected from a single center. While the low sample size did not allow us to perform substantial quantitative analyses, we were able to collect meaningful qualitative data from this patient group, which allowed us to gain insight into patient experiences with TSC and everolimus use. Additionally, a single center allows for homogeneity in clinical practice with respect to how everolimus therapy is administered and how patient information (e.g., side effects, AML sizes, etc.) is collected and recorded, reducing the potential of confounding variables. To support the generalizability of our findings, large, multicenter, prospective longitudinal studies need to be conducted on the asymptomatic TSC patient population.

\section{Conclusions}

Although AML size remains important in determining whether or not to initiate interventions for asymptomatic TSC-associated AMLs, other factors may also need to considered. A multitude of variables (AML size, functional kidney reserves, AML location, growth rate, risk of bleeding) were used in our center to classify patients as high- or low-risk. This was used to inform whether asymptomatic TSC patients received everolimus therapy or active surveillance. The favourable AML size outcomes for both everolimus and active surveillance groups provide support for using AML size alongside additional factors to determine an appropriate treatment. The influence of everolimus treatment burdens in deterring asymptomatic high-risk patients from starting or continuing everolimus therapy suggest that it may also be a significant factor for consideration. Larger, multicenter longitudinal studies are needed to validate the significance and benefits of weighing additional variables alongside AML size to determine if active surveillance or everolimus therapy is most appropriate for asymptomatic TSC patients. Based on our experience, patients with TSC-related AML can be safely managed with mTOR inhibitors such as everolimus, with shared decision making with the patient including factors such as risk of bleeding, rate of AML growth, and number and absolute size of AML. 


\section{References}

1. Henske EP, Jóźwiak S, Kingswood JC, et al. Tuberous sclerosis complex. Nat Rev Dis Primers 2016;2:1-18.

2. Randle SC. Tuberous sclerosis complex: A review. Pediatr Ann 2017;46:166-71.

3. Portocarrero LKL, Quental KN, Samorano LP, et al. Tuberous sclerosis complex: Review based on new diagnostic criteria. An Bras Dermatol 2018;93:323-31.

4. Amin S, Lux A, Calder N, et al. Causes of mortality in individuals with tuberous sclerosis complex. Dev. Med. Child Neurol 2017;59:612-17.

5. Bissler JJ, Kingswood JC, Radzikowska E, et al. Everolimus for angiomyolipoma associated with tuberous sclerosis complex or sporadic lymphangioleiomyomatosis (EXIST-2): A multicentre, randomised, double-blind, placebo-controlled trial. Lancet 2013;381:817-24.

6. Bhatt JR, Richard PO, Kim NS, et al. Natural history of renal angiomyolipoma (AML): Most patients with large AMLs $>4 \mathrm{~cm}$ can be offered active surveillance as an initial management strategy. Eur Urol 2016;70:85-90.

7. Flum AS, Hamoui N, Said MA, et al. Update on the diagnosis and management of renal angiomyolipoma. J Urol 2016;195:834-46.

8. Northrup H, Krueger DA. Tuberous sclerosis complex diagnostic criteria update: Recommendations of the 2012 International Tuberous Sclerosis Complex Consensus Conference. Pediatr Neurol 2013;49:243-54.

9. Ni J, Yan F, Qin W, et al. Mutational analysis of renal angiomyolipoma associated with tuberous sclerosis complex and the outcome of short-term everolimus therapy. Sci Rep 2019;9:14337.

10. Kingswood JC, Jozwiak S, Belousova ED, et al. The effect of everolimus on renal angiomyolipoma in patients with tuberous sclerosis complex being treated for subependymal giant cell astrocytoma: Subgroup results from the randomized, placebocontrolled, phase 3 trial EXIST-1. Nephrol Dial Transplant 2014 Jun;29:1203-10.

11. Bissler JJ, Nonomura N, Budde K, et al. Angiomyolipoma rebound tumor growth after discontinuation of everolimus in patients with tuberous sclerosis complex or sporadic lymphangioleiomyomatosis. PLoS One 2018;13:e0201005.

12. French JA, Lawson JA, Yapici Z, et al. Adjunctive everolimus therapy for treatmentresistant focal-onset seizures associated with tuberous sclerosis (EXIST-3): A phase 3, randomised, double-blind, placebo-controlled study. Lancet 2016;388:2153-63.

13. Dill PE, De Bernardis G, Weber P, et al. Topical everolimus for facial angiofibromas in the tuberous sclerosis complex. A first case report. Pediatr Neurol 2014;51:109-13.

14. Krueger DA, Wilfong AA, Holland-Bouley K, et al. Everolimus treatment of refractory epilepsy in tuberous sclerosis complex. Ann Neurol 2013;74:679-87.

15. Kapoor A, Girard L, Lattouf JB, et al. Evolving strategies in the treatment of tuberous sclerosis complex-associated angiomyolipomas (TSC-AML). Urology 2016;89:19-26.

16. Vaggers S, Rice P, Somani BK, et al. Evidence-based protocol-led management of renal angiomyolipoma: A review of literature. Turk J Urol 2020 Sep:1-10. Epub 2020 Sep 21. 
17. Eijkemans MJC, van der Wal W, Reijnders LJ, et al. Long-term follow-up assessing renal angiomyolipoma treatment patterns, morbidity, and mortality: An observational study in tuberous sclerosis complex patients in the Netherlands. Am J Kidney Dis 2015;66:638-45.

18. Kingswood JC, Bissler JJ, Budde K, et al. Review of the Tuberous Sclerosis Renal Guidelines from the 2012 Consensus Conference: Current data and future study. Nephron 2016;134:51-8.

19. Krueger DA, Northrup H; International Tuberous Sclerosis Complex Consensus Group. Tuberous sclerosis complex surveillance and management: Recommendations of the 2012 International Tuberous Sclerosis Complex Consensus Conference. Pediatr Neurol 2013;49:255-65.

20. Northrup H, Aronow ME, Bebin EM, et al. Updated International Tuberous Sclerosis Complex Diagnostic Criteria and Surveillance and Management Recommendations. Pediatr Neurol 2021;123:50-66. 


\section{Figures and Tables}

Fig. 1. (A) Contrast abdominal computed tomography showing $13.2 \mathrm{~cm}$ left renal angiomyolipoma (AML) with acute bleed. (B) AML decreased in size to $9.6 \mathrm{~cm}$ after nine months of everolimus therapy.
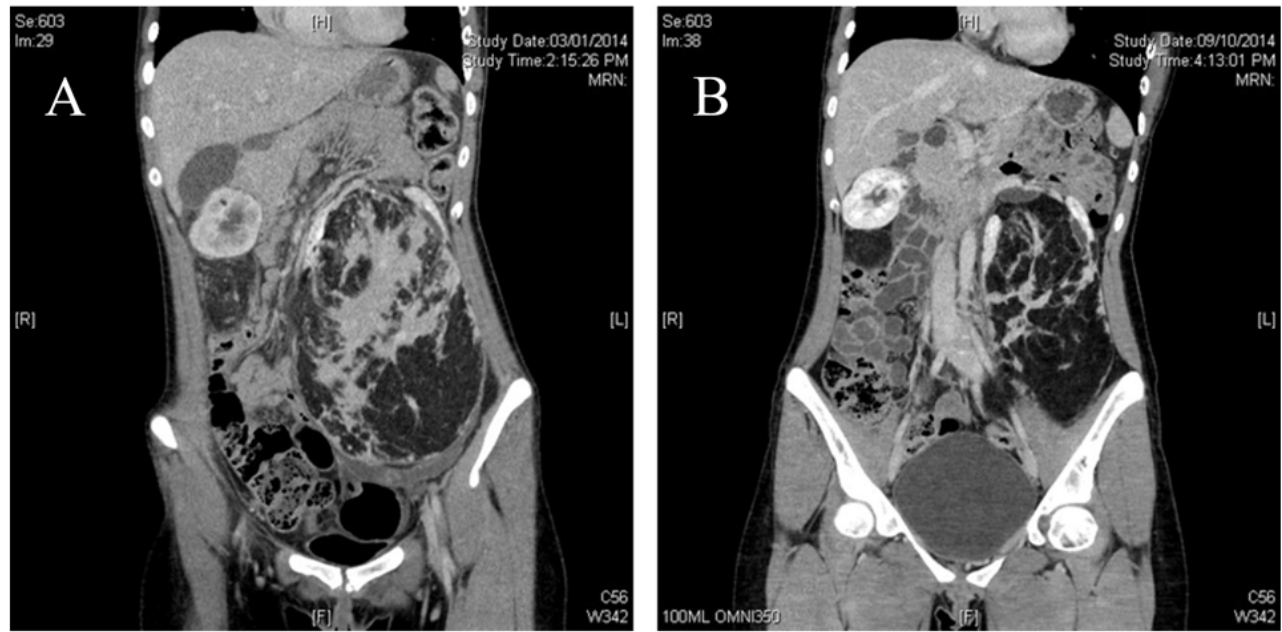

Fig. 2. Management algorithm for tuberous sclerosis complex (TSC)-associated angiomyolipoma (AML).

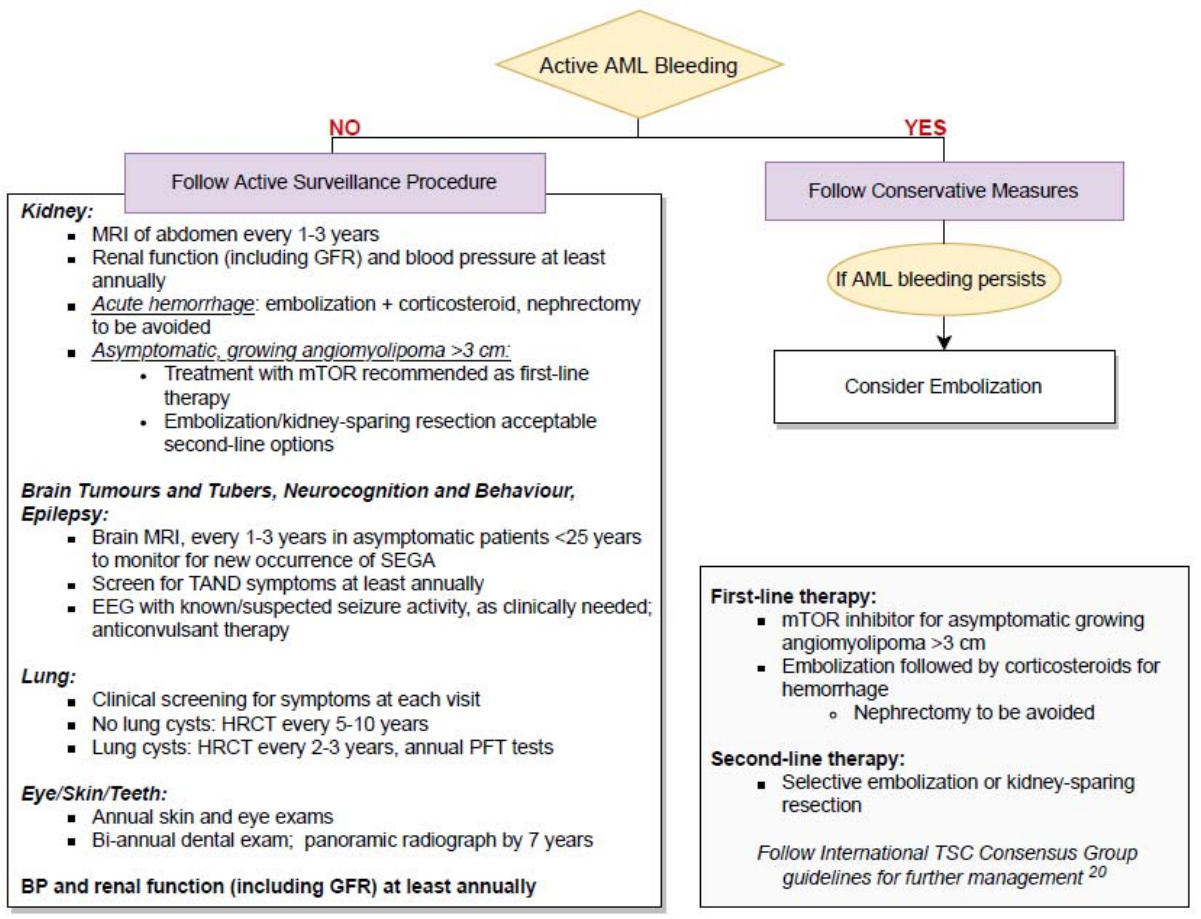

"SEGA: subependymal giant astrocytoma; TAND: TSC-associated neuropsychiatric disorders; EEG: electroencephalogram; HRCT: high-resolution CT; PFT: pulmonary function test, BP: blood pressure; GFR: glomerular filtration rate 


\begin{tabular}{|c|c|}
\hline Major features & Minor features \\
\hline $\begin{array}{l}\text { 1. Hypomelanotic macules ( } \geq 3 \text {, at least } 5 \mathrm{~mm} \text { in } \\
\text { diameter) }\end{array}$ & 1. "Confetti" skin lesions \\
\hline 2. Angiofibromas ( $\geq 3$ ) or fibrous cephalic plaque & 2. Dental enamel pits $(>3)$ \\
\hline 3. Ungual fibromas $(\geq 2)$ & 3. Intraoral fibromas $(\geq 2)$ \\
\hline 4. Shagreen patch & 4. Retinal achromic patch \\
\hline 5. Multiple retinal hamartomas & 5. Multiple renal cysts \\
\hline 6. Cortical dysplasias ${ }^{*}$ & 6. Nonrenal hamartomas \\
\hline 7. Subependymal nodules & (e \\
\hline 8. Subependymal giant cell astrocytomas & \\
\hline 9. Cardiac rhabdomyoma & \\
\hline 10. LAM $^{* *}$ & \\
\hline 11. Angiomyolipomas $(\geq 2)^{* *}$ & \\
\hline $\begin{array}{l}\text { Definite diagnosis: } \\
\text { - } 2 \text { major features or } \\
\text { - } 1 \text { major feature }+\geq 2 \text { minor } \\
\text { features }\end{array}$ & $\begin{array}{l}\text { diagnosis: } \\
\text { major feature or } \\
2 \text { minor features }\end{array}$ \\
\hline
\end{tabular}

"Includes tubers and cerebral white matter radial migration lines. ${ }^{* *} \mathrm{~A}$ combination of the two major features LAM and angiomyolipomas without other features does not meet criteria for a definite diagnosis. LAM: lymphangioleiomyomatosis; TSC: tuberous sclerosis complex. 


\begin{tabular}{|c|c|c|c|c|c|c|c|}
\hline \multirow[t]{2}{*}{ Patient } & \multirow[t]{2}{*}{ Age } & \multirow[t]{2}{*}{ Sex } & \multicolumn{3}{|c|}{ TSC manifestations } & \multirow{2}{*}{$\begin{array}{l}\text { Genetic } \\
\text { testing }\end{array}$} & \multirow{2}{*}{$\begin{array}{l}\text { Genetic } \\
\text { testing } \\
\text { result }\end{array}$} \\
\hline & & & Kidney & Brain & Other & & \\
\hline 1 & 44 & $\mathrm{~F}$ & $\begin{array}{l}\text { Renal AML } \\
\text { (bilateral) }\end{array}$ & Cortical tubers & None & No & \\
\hline 2 & 33 & $\mathrm{M}$ & $\begin{array}{l}\text { Renal AML } \\
\text { (bilateral) }\end{array}$ & None & $\begin{array}{l}\text { Hypomelanotic } \\
\text { macule, } \\
\text { angiofibromas }\end{array}$ & Yes & Negative \\
\hline 3 & 77 & $\mathrm{~F}$ & $\begin{array}{l}\text { Renal AML } \\
\text { (unilateral), } \\
\text { RCC, renal } \\
\text { cysts }\end{array}$ & None & $\begin{array}{l}\text { Hepatic AML, } \\
\text { Ungual } \\
\text { fibromas, } \\
\text { Shagreen } \\
\text { patch, Liver } \\
\text { AMLs, MMPH }\end{array}$ & No & \\
\hline 4 & 49 & $\mathrm{~F}$ & $\begin{array}{l}\text { Renal AML } \\
\text { (bilateral), } \\
\text { renal cysts }\end{array}$ & $\begin{array}{l}\text { SEN, SEGA, } \\
\text { Cerebral white } \\
\text { matter radial } \\
\text { migration lines }\end{array}$ & $\begin{array}{l}\text { Ungual } \\
\text { fibromas, } \\
\text { Shagreen } \\
\text { patch, liver } \\
\text { cysts }\end{array}$ & Yes & Unknown \\
\hline 5 & 24 & $\mathrm{~F}$ & $\begin{array}{l}\text { Renal } \\
\text { AMLs } \\
\text { (bilateral) }\end{array}$ & $\begin{array}{l}\text { SEN, SEGA, } \\
\text { cortical tubers, } \\
\text { brain cyst, } \\
\text { seizures }\end{array}$ & None & Yes & Positive \\
\hline 6 & 67 & $\mathrm{~F}$ & $\begin{array}{l}\text { Renal } \\
\text { AMLs } \\
\text { (bilateral) }\end{array}$ & Seizures & None & No & \\
\hline 7 & 60 & $\mathrm{~F}$ & $\begin{array}{l}\text { Renal } \\
\text { AMLs } \\
\text { (unilateral), } \\
\text { renal cysts }\end{array}$ & \begin{tabular}{|l|} 
Seizures, \\
cognitive \\
disability, \\
SEN, cortical \\
tubers
\end{tabular} & None & No & \\
\hline 8 & 16 & $\mathrm{M}$ & $\begin{array}{l}\text { Renal } \\
\text { AMLs } \\
\text { (bilateral), } \\
\text { renal cysts }\end{array}$ & $\begin{array}{l}\text { Cortical tubers, } \\
\text { seizures, } \\
\text { cognitive } \\
\text { disability }\end{array}$ & $\begin{array}{l}\text { Hypomelanotic } \\
\text { macules, } \\
\text { angiofibromas, } \\
\text { Shagreen } \\
\text { patch, retinal } \\
\text { hamartoma }\end{array}$ & Yes & Positive \\
\hline 9 & 43 & $\mathrm{M}$ & $\begin{array}{l}\text { Renal } \\
\text { AMLs } \\
\text { (bilateral), }\end{array}$ & None & Angiofibromas & Yes & Negative \\
\hline
\end{tabular}




\begin{tabular}{|c|c|c|c|c|c|c|c|}
\hline & & & $\begin{array}{l}\text { multiple } \\
\text { renal cysts }\end{array}$ & & & & \\
\hline 10 & 23 & $\mathrm{M}$ & $\begin{array}{l}\text { Renal } \\
\text { AMLs } \\
\text { (bilateral), } \\
\text { renal cysts, } \\
\text { SEN, SEGA }\end{array}$ & $\begin{array}{l}\text { Cortical tubers, } \\
\text { cerebral white } \\
\text { matter radial } \\
\text { migration lines }\end{array}$ & $\begin{array}{l}\text { Hypomelanotic } \\
\text { macules, } \\
\text { angiofibromas, } \\
\text { ungual } \\
\text { fibromas }\end{array}$ & No & \\
\hline 11 & 47 & $\mathrm{M}$ & $\begin{array}{l}\text { Renal cysts, } \\
\text { renal AMLs } \\
\text { (bilateral), } \\
\text { RCC }\end{array}$ & $\begin{array}{l}\text { Cortical } \\
\text { dysplasia, } \\
\text { seizures, } \\
\text { cognitive } \\
\text { disability, SEN }\end{array}$ & None & No & \\
\hline 12 & 49 & $\mathrm{M}$ & $\begin{array}{l}\text { Renal } \\
\text { AMLs } \\
\text { (unilateral), } \\
\text { renal cysts, } \\
\text { RCC }\end{array}$ & None & None & No & \\
\hline 13 & 28 & $\mathrm{M}$ & $\begin{array}{l}\text { Renal cysts, } \\
\text { renal AMLs } \\
\text { (bilateral) }\end{array}$ & SEN & None & Yes & Positive \\
\hline 14 & 26 & $\mathrm{~F}$ & $\begin{array}{l}\text { Renal } \\
\text { AMLs } \\
\text { (bilateral), } \\
\text { renal cysts }\end{array}$ & $\begin{array}{l}\text { Seizures, } \\
\text { cognitive } \\
\text { disability, } \\
\text { SEN, cortical } \\
\text { tubers }\end{array}$ & $\begin{array}{l}\text { Facial } \\
\text { sebaceum, } \\
\text { cardiac } \\
\text { rhabdomyoma, } \\
\text { MMPH, liver } \\
\text { cysts }\end{array}$ & No & \\
\hline 15 & 24 & $\mathrm{~F}$ & $\begin{array}{l}\text { Renal } \\
\text { AMLs } \\
\text { (bilateral), } \\
\text { renal cysts }\end{array}$ & $\begin{array}{l}\text { Infantile } \\
\text { spasms, } \\
\text { cerebral white } \\
\text { matter radial } \\
\text { migration lines, } \\
\text { SEN }\end{array}$ & None & No & \\
\hline 16 & 42 & $\mathrm{M}$ & $\begin{array}{l}\text { Renal } \\
\text { AMLs } \\
\text { (bilateral), } \\
\text { renal cysts }\end{array}$ & SEN & None & No & \\
\hline 17 & 32 & $\mathrm{~F}$ & Renal cyst & $\begin{array}{l}\text { Seizures, SEN, } \\
\text { cortical tubers, } \\
\text { neurobehaviora } \\
1 \text { abnormalities } \\
\text { (paranoid } \\
\text { schizophrenia) }\end{array}$ & None & No & \\
\hline
\end{tabular}




\begin{tabular}{|c|c|c|c|c|c|c|c|}
\hline 18 & 32 & F & $\begin{array}{l}\text { Renal } \\
\text { AMLs } \\
\text { (bilateral) }\end{array}$ & $\begin{array}{l}\text { SEN, SEGA, } \\
\text { cortical tubers, } \\
\text { white matter } \\
\text { radial } \\
\text { migration lines }\end{array}$ & Angiofibromas & No & \\
\hline 19 & $\begin{array}{l}58 \\
\text { (Dece } \\
\text { ased) }\end{array}$ & F & $\begin{array}{l}\text { Renal } \\
\text { AMLs } \\
\text { (bilateral), } \\
\text { renal cysts }\end{array}$ & None & $\begin{array}{l}\text { LAM, } \\
\text { angiofibromas, } \\
\text { liver cyst }\end{array}$ & No & \\
\hline 20 & 41 & $\mathrm{M}$ & $\begin{array}{l}\text { Renal cysts, } \\
\text { renal AMLs } \\
\text { (bilateral) }\end{array}$ & $\begin{array}{l}\text { SEGA, cortical } \\
\text { tubers, SEN, } \\
\text { cognitive } \\
\text { disability }\end{array}$ & Skin lesions & No & \\
\hline 21 & 28 & F & $\begin{array}{l}\text { Renal } \\
\text { AMLs } \\
\text { (bilateral) }\end{array}$ & $\begin{array}{l}\text { Cortical tubers, } \\
\text { SEN }\end{array}$ & $\begin{array}{l}\text { Lung cysts, } \\
\text { retinal } \\
\text { hamartoma }\end{array}$ & Yes & Positive \\
\hline
\end{tabular}

AML: angiomyolipoma; LAM: lymphangioleiomyomatosis; MMPH: multifocal micronodular pneumocyte hyperplasia; RCC: renal cell carcinoma; SEGA: subependymal giant cell astrocytoma; SEN: subependymal nodules; TSC: tuberous sclerosis complex.

\begin{tabular}{|c|c|c|c|c|}
\hline \multirow[t]{2}{*}{ Patient } & \multirow{2}{*}{$\begin{array}{l}\text { Acute } \\
\text { renal } \\
\text { AML } \\
\text { bleed? }\end{array}$} & \multicolumn{3}{|l|}{ TSC-related intervention } \\
\hline & & Surgery & Embolization & Everolimus \\
\hline 1 & No & No & Yes & Yes \\
\hline 2 & No & No & No & No \\
\hline 3 & No & $\begin{array}{l}\text { Yes (left radical nephrectomy, right } \\
\text { partial nephrectomy, } \\
\text { radiofrequency ablation) }\end{array}$ & No & No \\
\hline 4 & No & $\begin{array}{l}\text { Yes (incomplete radiofrequency } \\
\text { ablation) }\end{array}$ & No & No \\
\hline 5 & No & No & No & Yes \\
\hline 6 & No & No & No & No \\
\hline 7 & No & No & No & No \\
\hline 8 & Yes & Yes (Right parietal lobe excision) & No & Yes \\
\hline 9 & No & No & No & No \\
\hline 10 & No & $\begin{array}{l}\text { Yes (Resection of intraventricular } \\
\text { tumor - left subependymal giant } \\
\text { cell astrocytoma) }\end{array}$ & No & No \\
\hline 11 & No & No & No & No \\
\hline
\end{tabular}




\begin{tabular}{|l|l|l|l|l|}
\hline 12 & No & Yes & No & No \\
\hline 13 & No & No & No & No \\
\hline 14 & Yes & $\begin{array}{l}\text { Yes (vagus nerve stimulation } \\
\text { implantation, radical left } \\
\text { nephrectomy, resection of right } \\
\text { frontal cortical tuber) }\end{array}$ & No & Yes \\
\hline 15 & Yes & No & No & Yes \\
\hline 16 & Yes & No & No & No \\
\hline 17 & No & No & No & No \\
\hline 18 & No & No & No & Yes \\
\hline 19 & Yes & Yes (partial right nephrectomy) & No & No \\
\hline 20 & Yes & $\begin{array}{l}\text { Yes (ventriculoperitoneal shunt, } \\
\text { ureteric stent) }\end{array}$ & Yes & Yes \\
\hline 21 & Yes & No & Yes & Yes \\
\hline
\end{tabular}

TSC: tuberous sclerosis complex.

\begin{tabular}{|c|c|c|}
\hline Patient & Side effects & Benefits of everolimus \\
\hline 1 & $\begin{array}{l}\text { Mucositis } \\
\text { Vomiting } \\
\text { Headache } \\
\text { Nausea } \\
\text { Lack of menses }\end{array}$ & Decreased AML size \\
\hline 5 & $\begin{array}{l}\text { Mucositis } \\
\text { Headache } \\
\text { Nausea }\end{array}$ & $\begin{array}{l}\text { Decreased AML size } \\
\text { Decreased angiofibroma size } \\
\text { Decreased seizure frequency and severity }\end{array}$ \\
\hline 8 & None & $\begin{array}{l}\text { Decreased AML size } \\
\text { Decreased seizures }\end{array}$ \\
\hline 14 & $\begin{array}{l}\text { Mucositis } \\
\text { Nausea } \\
\text { Weight loss }\end{array}$ & $\begin{array}{l}\text { Decreased AML size } \\
\text { Improvement in skin manifestations }\end{array}$ \\
\hline 15 & None & Decreased AML size \\
\hline 18 & None & Not yet evaluated $^{*}$ \\
\hline 20 & $\begin{array}{l}\text { Elevated cholesterol and } \\
\text { triglycerides }\end{array}$ & $\begin{array}{l}\text { Decreased AML size } \\
\text { Improved seizure frequency } \\
\text { Improved skin lesions } \\
\text { Brighter mentality (more aware) } \\
\text { Decrease in size of brain lesions and cortical } \\
\text { tubers }\end{array}$ \\
\hline
\end{tabular}




\begin{tabular}{|l|l|l|}
\hline 21 & $5 \mathrm{mg}: \begin{array}{l}\text { Flank pain } \\
\text { Nausea } \\
\text { Lack of appetite }\end{array}$ & $\begin{array}{l}\text { Decreased AML size } \\
\text { No hematuria }\end{array}$ \\
$2.5 \mathrm{mg}:$ No pain & \\
\hline
\end{tabular}

AML: angiomyolipoma. *Patient 18 initiated everolimus therapy towards the end of the study period. Information on its benefits for patient 18 was not available.

\begin{tabular}{|c|c|c|c|c|}
\hline Patient & $\begin{array}{l}\text { Dosage } \\
\text { (mg/day) }\end{array}$ & $\begin{array}{l}\text { AML size changes and } \\
\text { clinical benefits }\end{array}$ & Adverse effects & \begin{tabular}{|l}
$\begin{array}{l}\text { Reason for dosage } \\
\text { change }\end{array}$ \\
\end{tabular} \\
\hline \multirow[t]{3}{*}{1} & $10 \mathrm{mg}$ & & $\begin{array}{l}\text { Nausea, headaches, } \\
\text { nausea }\end{array}$ & \\
\hline & $5 \mathrm{mg}$ & $\begin{array}{l}-36 \% \text { left } A M L \\
-19 \% \text { right } A M L\end{array}$ & Lack of menses & $\begin{array}{l}10 \text { to } 5 \mathrm{mg}: \text { minor side } \\
\text { effects at } 10 \mathrm{mg} \\
\text { dosage }\end{array}$ \\
\hline & $0 \mathrm{mg}$ & $+13 \%$ right $\mathrm{AML}$ & & $\begin{array}{l}5 \mathrm{mg} \text { to } 0 \mathrm{mg}: \text { As per } \\
\text { treatment plan }\end{array}$ \\
\hline 5 & $5 \mathrm{mg}$ & Decreased AMLs & $\begin{array}{l}\text { Headache, nausea, } \\
\text { canker sores in mouth } \\
\text { mucositis (responsive to } \\
\text { viscous lidocaine } \\
\text { mouthwash) }\end{array}$ & \\
\hline \multirow[t]{2}{*}{8} & $5 \mathrm{mg}$ & $\begin{array}{l}-44 \% \text { left AML } \\
-29 \% \text { right AML } \\
\text { Decreased seizure } \\
\text { frequency and severity }\end{array}$ & None & \\
\hline & $7.5 \mathrm{mg}$ & $\begin{array}{l}+2 \% \text { left } \mathrm{AML} \\
-14 \% \text { right } \mathrm{AML}\end{array}$ & None & $\begin{array}{l}\text { 5-7.5 mg: To target } \\
\text { patient's cortical } \\
\text { tubers }\end{array}$ \\
\hline \multirow[t]{4}{*}{14} & $5 \mathrm{mg}$ & $\begin{array}{l}-11 \% \\
\text { Improved skin } \\
\text { manifestations }\end{array}$ & $\begin{array}{l}\text { Significant mucositis, } \\
\text { oral lesions, weight loss }\end{array}$ & \\
\hline & $0 \mathrm{mg}$ & $-13 \%$ & & Side effects \\
\hline & $2.5 \mathrm{mg}$ & $\begin{array}{l}-25 \% \\
\text { Facial sebaceum } \\
\text { decreased }\end{array}$ & Fewer mouth sores & \\
\hline & $5 \mathrm{mg}$ & Not yet evaluated & & $\begin{array}{l}\text { To further improve } \\
\text { skin lesions and } \\
\text { decrease AML size }\end{array}$ \\
\hline 15 & $5 \mathrm{mg}$ & $-35 \%$ right $\mathrm{AML}$ & None & \\
\hline
\end{tabular}




\begin{tabular}{|l|l|l|l|l|}
\hline & & $-18 \%$ left AML & & \\
\hline 18 & $5 \mathrm{mg}$ & Not yet evaluated & None & \\
\hline 20 & $7.5-10 \mathrm{mg}$ & $\begin{array}{l}\text { Reductions in AMLs, } \\
\text { brain lesions, cortical } \\
\text { tubers; improvements in } \\
\text { seizure frequency, skin } \\
\text { lesions and cognitive } \\
\text { awareness. }\end{array}$ & $\begin{array}{l}\text { High nitrates and } \\
\text { leukocytes in urine }\end{array}$ & \\
\hline 21 & $5 \mathrm{mg}$ & Not yet evaluated & Stomach cramps, nausea, & Due to proteinuria \\
\cline { 2 - 6 } & $5 \mathrm{mg}$ & $-9 \%$ left AML & $\begin{array}{l}\text { Slank pain, suprapubic } \\
\text { discomfort, facial rashes. }\end{array}$ & \\
\cline { 2 - 6 } & $0 \mathrm{mg}$ & $+20 \%$ left AML & Renal bleeds & $\begin{array}{l}\text { Treatment stopped } \\
\text { temporarily due to } \\
\text { stomach pain }\end{array}$ \\
\cline { 2 - 5 } & $2.5 \mathrm{mg}$ & $+22 \%$ left AML & & \\
\hline
\end{tabular}

AML: angiomyolipoma. 